\title{
Calcium-Channel Blockers in Patients with Radial Artery Grafts.
}

\author{
Marco Moscarelli ${ }^{1}$ and Mario Gaudino ${ }^{2}$ \\ ${ }^{1}$ GVM Care and Research \\ ${ }^{2}$ NewYork-Presbyterian Hospital/Weill Cornell Medical Center
}

January 13, 2021

\begin{abstract}
The use of radial artery (RA) grafts for coronary bypass surgery has recently gained newer attention since it has been associated with significant reduction in the risk of midterm cardiac events. Surprisingly the use on the RA graft as second 'best' conduit has been limited among the surgical community. There may be several explanations for the little popularity of the RA graft; one of the reasons that could prevent surgeons to include the RA in the daily surgical armamentarium it is that patients with RA grafts may require postoperative calcium-channel blocker (CB) therapy. Due to the thick muscular wall, it seems possible that the RA would needs CB in order to prevent spasm and ameliorate patency. CBs are, however, associated with important side effects; also they have hypotensive effect that can hamper the use of other therapy such as beta-blocker or angiotensinconverting enzyme inhibitors. The evidence supporting the use of CB after RA graft (either in the early phase or as chronic calcium-blocker (CCB)) is weak. A the post-hoc analysis from the 'RADIAL' (Radial Artery Database International ALliance), showed that in patients with RA, the use of CB for at least 12 months was associated with better clinical and angiographic outcomes at mid-term follow-up, but confounders and bias may be responsible for the reported findings (as healthier patients are more likely to tolerate CB). This review aims to summarize current evidences available on the topic and to serve as benchmark for evidence-based decision-making for CB prescription after RA grafting.
\end{abstract}

\section{Introduction}

The first use of the RA as conduit for coronary artery bypass grafting is dated back in 1973 when Carpentier and colleagues published a case series of 30 patients $^{1}$; the authors explored the RA potential due to the larger diameter, ease of dissection and generally more suitability for suturing. Ten months after the operation all the graft were opened, however they warned against early optimism because it needed to be 'ascertained whether the arterial conduits were threatened by the same modifications as those observed in the venous grafts' $^{\prime 2}$. Later on, in fact, the authors advised RA use to be discontinued because of a $30 \%$ incidence of graft occlusion.

Shortly after, other Authors also reported high rates of spasm and early occlusion and eventually the RA was abandoned for some times ${ }^{3}$.

Out of serendipity, almost 20 years later, a patient in whom postoperative angiography showed total occlusion was restudied and surprisingly the RA was fully patent, most importantly, with no evidences of atherosclerotic disease. Three other patients were re-studied, with similar angiographic results. These findings attracted newer attention of the potential use of RA as alternative graft for coronary surgery. Hence, Carpentier restarted the RA use, this time using CB, during and after the operation ${ }^{2}$ and in 1992, published a paper titled: 'Revival of the radial artery for coronary artery bypass grafting', where significant improved patency was reported ${ }^{4}$.

It was suggested that the 'key' for preserving RA patency perhaps was the use of CB since the very early start of the harvesting and the prescription as chronic antispastic agents. The concern of spasm with the RA 
use is indeed related to its unique histologic structures that significantly differ from all the other conduits routinely used for CABG.

\section{The anatomy and morphology of the radial artery}

Arteries can be classified into three types: a) type 1: 'somatic' b) type 2: 'splanchnic' c) type 3: 'limb arteries $^{25,6}$. The RA is an example of type 3 artery. As the other arteries, the RA has three layer of tunica. The tunica intima is a thin layer with a prominent internal elastic membrane. The tunica media contains myocytes, connective tissue and elastic fibers. The tunica adventitia is very prominent and mainly consists of collagen and elastic fibers, fibroblast and clusters of smooth muscle cells. Notably, there are also adventitial sympathetic and parasympathetic nerves that might be involved in arterial spasm.

The RA is also defined as 'muscular artery' given the abundant myocytes in the media layer ${ }^{7}$. The more muscular media compared to the left internal mammary artery (LIMA) is the theoretical background for the described concerns of RA spasm ${ }^{8}$. Chester et al. demonstrated that there are more muscle cells in the proximal RA vessel compared to the distal RA, as well as variation in the profile of adrenoceptors along the RA vessel ${ }^{9}$.

Notably, the RA vasa vasorum do not penetrate into the media and nutrients and oxygen are provided by luminal diffusion; this may suggest that its use as free graft should not be subjected to ischemic events over the long term. However that was challenged by other studies. van Son and colleagues measured a mean width in the media of the RA approximately $500 \mu \mathrm{m}$, as opposed to $330 \mu \mathrm{m}$ for that of the LIMA, $280 \mu \mathrm{m}$ for that of the gastroepiploic artery and $240 \mu \mathrm{m}$ for the inferior epigastric artery ${ }^{10}$. These authors suggested that the RA thick media layer can be prone to fibrosis by the time, given the low oxygen penetration at this level ${ }^{10}$.

Local factors and systemic hormones can modulate RA vasoconstriction acting at the level of the receptors in the vascular smooth cells. The RA endothelium is pivotal in regulating smooth muscle activity ${ }^{5}$. Vasodilation in fact can be achieved by the release of endothelium derived nitric oxide, prostaglandin and prostacyclin. Endothelin -1, thromboxane A2 and prostaglandin $2 \mathrm{a}$ are among the most potent vasoconstrictors. In terms of systemic hormones, angiotensin II and arginine vasopressin are both potent vasoconstrictor even at low concentration acting by opening calcium channels and via the $\alpha 1$-adrenergic receptor ${ }^{5}$.

Remarkably, there is also evidence of cross-talk between signaling pathway that mediate vascular contraction and those that are involved with muscle cell growth; RA vessel contraction and spasm can be an important step in the activation of growth-promoting pathways ${ }^{11}$.

There are some concerns with regard to pre-existing disease in the radial artery; analysis from histological specimens from 177 radial arteries showed increased prevalence of intimal thickening, medial sclerosis and calcification in the radial artery compared to other conduits ${ }^{12}$.

In summary, the functional and morphological anatomy of the RA is very complex and the way it reacts to internal or external stimuli remains, also, not fully understood. There are a number of mechanisms that can be responsible for vasodilation and vasoconstriction; thereby, it is unlikely that a single agent could completely eliminate RA spasm.

\section{Best evidence topics (BETs) supporting the use of CB after RA graft}

There are few randomized controlled trials (RCT) and some comparative studies that investigated the early and chronic role of CB after RA grafting (Table 1). However, given the high patency rate of the RA grafts, it is possible that all the published studies were largely underpowered to detect even moderate differences in outcome.

In Broadman et al. study $^{13}$, sixty patients underwent post operative angiography between 1 day and 40 weeks; of these 28 were on CB. Patency rate of the radial arteries was $95.7 \%$ and there was no association with CB usage. 
Acar et al. $^{3}$ followed up 50 patients. At long-term follow-up angiography (5-7 years) there were no differences in terms of graft failure among patients on $\mathrm{CB}$ treatment $(\mathrm{N}=27)$ versus the one who had not $\mathrm{CB}(\mathrm{N}=23)$.

Possati et $\mathrm{al}^{14}$ followed up 90 patients with RA. All patients received diltiazem for a year postoperatively and 51 patients stopped the medication during the follow-up. There was no difference in graft patency between patients who continued or suspended CB. The same group reported similar results in $2003^{15}$. Similarly, Arena et al. did not find differences in terms of graft patency in patients with or without 6-months CB therapy ${ }^{16}$.

Shapira et al. ${ }^{17}$ randomized 161 patients to postoperative diltiazem or nitrates; key in-hospital and follow-up clinical end points such as mortality, major morbidity, myocardial infarction, use of inotropic agents and need for cardiac catheterization, and reintervention were similar between the two groups.

A 2001 RCT from Gaudino et al. ${ }^{18}$ assigned 57 and 63 patients to early regimen (1 year) and to chronic regimen $\mathrm{CB}$ respectively. After 5 years, patients were reassessed clinically and by stress myocardial scintigraphy; 87 of them were re-studied angiographically. They found no differences regarding either the clinical and scintigraphic results or the RA angiographic status. They concluded that after the first post-operative year the continuation of CB did not affect RA graft patency or clinical and scintigraphic results.

In 2005, the same author randomized 53 and 47 patients to receive and to no receive CCB immediately after RA grafting ${ }^{19}$. At 1-year follow-up all patients were reassessed clinically and scintigraphically; 83 of them were re-studied angiographically. Again, no differences in terms of clinical outcome, scintigraphic result and patency rate was found between groups.

Gaudino et al. in fact questioned the chronic use of CB since they demonstrated that 1 year after implantation in the coronary artery circulation, the RA tends to lose the muscular component, becoming similar to the LIMA $^{20}$.

Moran et al. ${ }^{21}$ followed-up 63 and 52 patients after RA grafting with and without CB respectively. Coronary angiographies were obtained at 1-year in 50 patients. No differences were observed for clinical and angiographic end points in the patients that received $\mathrm{CB}$ compared with those who had not.

Cameron et al. ${ }^{22}$ performed angiogram 5 years post RA grafting in 50 patients; 37 of these patients received CB. The patency rate was high $(89 \%)$ and no correlation with CCB usage was found.

A post-hoc analysis of the Radial Artery Patency Study ${ }^{23}$ found that among 440 RA patients, the incidence of RA spasm was not associated with the compliance with the prescribed postoperative $\mathrm{CB}$, although compliance with CB use was high (419 of 440 patients).

Finally, a post-hoc analysis of the Radial Artery Database International ALliance analyzed ${ }^{24}$ patient-level database included 732 patients (502 on CCB). At median follow-up of 55 months, CCB therapy of at least 1 year was found to be associated with significantly lower risk of MACE and RA graft occlusion.

Nevertheless, despite the lack of definitive evidences, the use of CB after RA grafting is considered 'routine' in many centers. A 2003 survey of Canadians cardiac units showed that the vast majority of the surgeons and physicians prescribed CB or other forms of anti-spastic therapy after RA grafting ${ }^{25}$.

Table 1. Best evidences Topics (BETs): 'Calcium-channel use after RA grafting'.

\begin{tabular}{llllll}
\hline Study, Year & Study type & $\begin{array}{l}\text { Calcium } \\
\text { Channel } \\
\text { Blocker }\end{array}$ & Groups & Follow-up & Conclusion \\
$\begin{array}{l}\text { Broadman et al. } \\
\text { Sample size=60 }\end{array}$ & Case control & $\begin{array}{l}\text { Diliazem } 240 \\
\text { mg daily }\end{array}$ & $\begin{array}{l}\text { a) } \mathrm{N}=28 \text { with } \\
\text { CB b) N=28 no }\end{array}$ & Mean 3-months & $\begin{array}{l}\text { No difference in } \\
\text { terms of patency } \\
\text { rate between the } \\
\text { two groups }\end{array}$
\end{tabular}




\begin{tabular}{|c|c|c|c|c|c|}
\hline $\begin{array}{l}\text { Acar et al }{ }^{3} \\
\text { Sample size }=50 \\
1998\end{array}$ & Case control & $\begin{array}{l}\text { Diltiazem } 250 \\
\text { mg daily }\end{array}$ & $\begin{array}{l}\text { a) } N=27 \text { with } \\
\text { CB b) } N=23 \text { no } \\
\text { CB }\end{array}$ & 4/7-years & $\begin{array}{l}\text { No differences in } \\
\text { terms of graft } \\
\text { failure }\end{array}$ \\
\hline $\begin{array}{l}\text { Possati et al. }{ }^{14} \\
\text { Sample size }=68 \\
1998\end{array}$ & Case-control & $\begin{array}{l}\text { Diltiazem } 120 \\
\text { mg twice a day }\end{array}$ & $\begin{array}{l}\text { After the } 1 \text { year } \\
\text { those without } \\
\text { scintigraphic or } \\
\text { angiographic } \\
\text { evidence of } \mathrm{RA} \\
\text { territory } \\
\text { ischemia } \\
\text { assigned to: a) } \\
\mathrm{N}=29 \text { continued } \\
\mathrm{CB} \text { b) } \mathrm{N}=31 \\
\text { suspended } \mathrm{CB}\end{array}$ & 5 -years & $\begin{array}{l}\text { No differences in } \\
\text { RA graft status } \\
\text { could be shown } \\
\text { between groups } \\
\text { who continued } \\
\text { or suspended } \\
\text { therapy with } \\
\text { calcium channel } \\
\text { blockers after } 1 \\
\text { year. }\end{array}$ \\
\hline $\begin{array}{l}\text { Arena et al } \\
\text { Sample size }=50 \\
2000^{16}\end{array}$ & $\mathrm{RCT}$ & $\begin{array}{l}\text { Nifedipine } 40 \\
\text { daily for } 6 \\
\text { months post-op }\end{array}$ & $\begin{array}{l}\text { a) } \mathrm{N}=26 \text { with } \\
\mathrm{CB} \text { b) } \mathrm{N}=24 \text { no } \\
\mathrm{CB}\end{array}$ & 16-24 months & $\begin{array}{l}\text { No difference in } \\
\text { terms of patency } \\
\text { rate between the } \\
\text { two groups }\end{array}$ \\
\hline $\begin{array}{l}\text { Shapira et al. }{ }^{17} \\
\text { Sample size }=161 \\
2000\end{array}$ & $\mathrm{RCT}$ & $\begin{array}{l}\text { Diltiazem and } \\
\text { GTN }\end{array}$ & $\begin{array}{l}\text { a) } \mathrm{N}=77 \text { patients } \\
\text { with diltiazem } \\
\text { infusion for } 24 \mathrm{~h} \\
\text { and daily for } 6 \\
\text { months } \\
\text { thereafter } \mathrm{n}=77 \\
\text { b) } \mathrm{N}=84 \\
\text { patients with } \\
\mathrm{GTN} \text { infusion for } \\
24 \mathrm{~h} \text { and daily } \\
\text { nitrate therapy } \\
\text { for } 6 \text { months } \\
\text { thereafter. }\end{array}$ & 6-months & $\begin{array}{l}\text { Major } \\
\text { in-hospital and } \\
\text { follow-up clinical } \\
\text { end points } \\
\text { (mortality, } \\
\text { major morbidity, } \\
\text { myocardial } \\
\text { infarction, use of } \\
\text { inotropic agents, } \\
\text { the need for } \\
\text { cardiac } \\
\text { catheterization, } \\
\text { and } \\
\text { reintervention) } \\
\text { similar between } \\
\text { the study groups }\end{array}$ \\
\hline $\begin{array}{l}\text { Gaudino et al. } \\
18 \text { Sample } \\
\text { size }=1202001\end{array}$ & $\mathrm{RCT}$ & $\begin{array}{l}\text { Diltiazem } 120 \\
\text { mg/day }\end{array}$ & $\begin{array}{l}\text { a) } \mathrm{N}=57 \text { patients } \\
\text { suspended } \mathrm{CB} \\
\text { after } 1 \text { year b) } \\
\mathrm{N}=63 \text { patients } \\
\text { with chronic } \mathrm{CB} \\
\text { use }\end{array}$ & 5 -year & $\begin{array}{l}\text { No difference in } \\
\text { graft patency, } \\
\text { graft reactivity, } \\
\text { myocardial } \\
\text { ischemia or } \\
\text { clinical outcomes }\end{array}$ \\
\hline $\begin{array}{l}\text { Moran et al. }{ }^{21} \\
\text { Sample size }=115 \\
2001\end{array}$ & Case-control & $\begin{array}{l}\text { Diltiazem } 1 \\
\mu \mathrm{g} / \mathrm{kg} / \mathrm{min} \\
\text { intraoperatively } \\
\text { then } 180 \mathrm{mg} / \text { day } \\
\text { for } 1 \text { year }\end{array}$ & $\begin{array}{l}\text { a) } \mathrm{N}=63 \text { patients } \\
\text { with } \mathrm{CB} \text { b) } \\
\mathrm{N}=52 \text { patients } \\
\text { with no } \mathrm{CB}\end{array}$ & 1-year & $\begin{array}{l}\text { The degree of } \\
\text { the native } \\
\text { coronary artery } \\
\text { stenosis } \\
\text { influenced the } \\
\text { patency rate of } \\
\text { RA, independent } \\
\text { of the CB }\end{array}$ \\
\hline
\end{tabular}




\begin{tabular}{|c|c|c|c|c|c|}
\hline $\begin{array}{l}\text { Possati et al. }{ }^{15} \\
\text { Sample size }=90 \\
2003\end{array}$ & Case-control & $\begin{array}{l}\text { Diltiazem } 120 \\
\text { mg daily }\end{array}$ & $\begin{array}{l}\text { After } 1 \text { year, a) } \\
\mathrm{N}=51 \text { patients } \\
\text { stopped CB b) } \\
\mathrm{N}=49 \text { patients } \\
\text { on } \mathrm{CB}\end{array}$ & $105 \pm 9$ months & $\begin{array}{l}\text { No differences in } \\
\text { graft patency } \\
\text { between two } \\
\text { groups }\end{array}$ \\
\hline $\begin{array}{l}\text { Cameron et al. }{ }^{22} \\
\text { Sample size }=50 \\
2004\end{array}$ & Case-control & $\begin{array}{l}\text { Diltiazem / } \\
\text { amlodipine / } \\
\text { verapamil } \\
\text { /nifedipine }\end{array}$ & $\begin{array}{l}\text { a) } N=37 \text { with } \\
\mathrm{CB} \text { b) } N=23 \text { no } \\
\mathrm{CB}\end{array}$ & 5 -years & $\begin{array}{l}\text { No correlation } \\
\text { found between } \\
\text { CB usage and } \\
\text { angiographic } \\
\text { patency }\end{array}$ \\
\hline $\begin{array}{l}\text { Gaudino et al. }{ }^{19} \\
\text { Sample size }=100 \\
2005\end{array}$ & $\mathrm{RCT}$ & $\begin{array}{l}\text { Diltiazem } 120 \\
\text { mg daily }\end{array}$ & $\begin{array}{l}\text { a) } \mathrm{N}=53 \\
\text { patients with } \mathrm{CB} \\
\text { early regimen b) } \\
\mathrm{N}=47 \text { patients } \\
\text { with no } \mathrm{CB}\end{array}$ & 1-year & $\begin{array}{l}\text { No difference } \\
\text { graft patency / } \\
\text { reactivity / } \\
\text { ischemia }\end{array}$ \\
\hline $\begin{array}{l}\text { Radial Artery } \\
\text { Patency Study } \\
\text { Sample size }=440 \\
2006\end{array}$ & $\begin{array}{l}\text { RCT Post-hoc } \\
\text { analysis }\end{array}$ & $\begin{array}{l}\text { Nifedipine for } 6 \\
\text { months post-op }\end{array}$ & $\begin{array}{l}\text { a) } \mathrm{N}=419 \\
\text { patients with } \\
\text { compliance to } \\
\mathrm{CB} \text { b) } \mathrm{N}=21 \\
\text { patients with no } \\
\text { compliance to } \\
\mathrm{CB}\end{array}$ & 1-year & $\begin{array}{l}\text { The incidence of } \\
\text { string sign (RA } \\
\text { spasm) was not } \\
\text { affected by the } \\
\text { compliance with } \\
\text { the prescribed } \\
\text { CB. }\end{array}$ \\
\hline $\begin{array}{l}\text { Radial Artery } \\
\text { Database } \\
\text { International } \\
\text { ALliance }^{24} \\
\text { Sample size=732 } \\
2019\end{array}$ & $\begin{array}{l}\text { RCT Post-hoc } \\
\text { analysis }\end{array}$ & $\begin{array}{l}\text { Diltiazem / } \\
\text { amlodipine }\end{array}$ & $\begin{array}{l}\text { a) } \mathrm{N}=502 \\
\text { patients with } \mathrm{CB} \\
\text { B) } \mathrm{N}=230 \\
\text { patients with no } \\
\text { CB }\end{array}$ & $\begin{array}{l}\text { Median } \\
\text { angiographic } \\
\text { follow-up } 55 \\
\text { months }\end{array}$ & $\begin{array}{l}\text { CB therapy was } \\
\text { found to be } \\
\text { consistently } \\
\text { associated with a } \\
\text { significant lower } \\
\text { risk of MACE } \\
\text { and RA graft } \\
\text { occlusion }\end{array}$ \\
\hline $\begin{array}{l}\text { CB: Calcium- } \\
\text { channel } \\
\text { blocker. } \\
\text { MACE: Major } \\
\text { adverse } \\
\text { cardiac events. } \\
\text { RCT: } \\
\text { randomized } \\
\text { controlled } \\
\text { trial. }\end{array}$ & $\begin{array}{l}\text { CB: Calcium- } \\
\text { channel } \\
\text { blocker. } \\
\text { MACE: Major } \\
\text { adverse } \\
\text { cardiac events. } \\
\text { RCT: } \\
\text { randomized } \\
\text { controlled } \\
\text { trial. }\end{array}$ & $\begin{array}{l}\text { CB: Calcium- } \\
\text { channel } \\
\text { blocker. } \\
\text { MACE: Major } \\
\text { adverse } \\
\text { cardiac events. } \\
\text { RCT: } \\
\text { randomized } \\
\text { controlled } \\
\text { trial. }\end{array}$ & $\begin{array}{l}\text { CB: Calcium- } \\
\text { channel } \\
\text { blocker. } \\
\text { MACE: Major } \\
\text { adverse } \\
\text { cardiac events. } \\
\text { RCT: } \\
\text { randomized } \\
\text { controlled } \\
\text { trial. }\end{array}$ & $\begin{array}{l}\text { CB: Calcium- } \\
\text { channel } \\
\text { blocker. } \\
\text { MACE: Major } \\
\text { adverse } \\
\text { cardiac events. } \\
\text { RCT: } \\
\text { randomized } \\
\text { controlled } \\
\text { trial. }\end{array}$ & $\begin{array}{l}\text { CB: Calcium- } \\
\text { channel } \\
\text { blocker. } \\
\text { MACE: Major } \\
\text { adverse } \\
\text { cardiac events. } \\
\text { RCT: } \\
\text { randomized } \\
\text { controlled } \\
\text { trial. }\end{array}$ \\
\hline
\end{tabular}

\section{Choice of calcium-channels blockers after RA grafting and side effect}

There is a wide range of $\mathrm{CB}$; however, there are three main chemically divergent groups: dihydropyridines (eg, nifedipine, amlodipine, nicardipine, clevidipine and nicorandil), phenylalkylamines (eg, verapamil), and benzothiazepines (eg, diltiazem) ${ }^{26}$.

The choice of CB to prevent RA spasm has been empirical.

At least theoretically, all CB derivatives can be used to prevent RA graft spasm; nevertheless it has been demonstrated that dihydropyridine are the most potent vasodilator ${ }^{27}$. However, the vast majority of the studies published in literature used diltiazem as antispasmodic agent (table 1). 
He and colleagues in a in-vitro study found that nifedipine was 19.5-fold more potent than verapamil and 31.6-fold more potent than diltiazem in RA precontracted with potassium; also, its efficacy on prevention of RA spasm was shown by the observation that at the usual plasma concentration, nifedipine significantly reduced RA contraction, whereas neither verapamil nor diltiazem had any effect on the RA contraction at equal concentration ${ }^{26}$.

Diltiazem may have significant negative chronotropic and inotropic effects. Its early use can increase the requirement for temporary cardiac pacing in the post-operative period.

Amlodipine is a more selective $\mathrm{CB}$, thereby with less effect on the myocardium.

However, Kloner et al. ${ }^{28}$ reported that in patients with amlodipine, edema occurred in $24 \%$, headache in $8.8 \%$ and in fatigue and dizziness in $>4 \%$.

Notably, the potential hypotensive effect of the CB may preclude the use of other secondary prevention therapies such as beta-blockers or angiotensin-converting enzyme inhibitors.

Polypharmacy is also an important concern and has been associated with increased risk of cardiac events ${ }^{29}$.

\section{Key factors influencing the RA patency}

Besides the $\mathrm{CB}$ prescription, whose utility is still under investigation, there are other factors that might influence RA graft patency or at least 'interact' with the $\mathrm{CB}$ in order to contribute to RA longevity ${ }^{30}$. Briefly, those are:

a) appropriate coronary target selection b) meticulous and scrupulous harvesting technique (either open or endoscopic) and a c) a general 'no touch technique', avoiding hyperinflation of the conduits that can lead to potential for damage of the RA intima and internal elastic lamina.

With regard to target selection, rather than the location of the target vessel it seem far more important to consider the severity of the coronary stenosis; the reversal of one case of string sign concomitant with the progression of the coronary stenosis, although anecdotal, further underscore the influence of native, competitive flow on RA graft ${ }^{15}$. Royse and colleagues ${ }^{31}$ defined $70 \%$ coronary stenosis as the 'cut-off' point; below this degree of stenosis the long-term patency of the RA was found to be significantly reduced. Desai and colleagues recommended the use of RA graft only for severely stenotic vessel $(>90 \%)^{32}$.

The most common adopted vasodilators for intraoperative dilatation during RA harvesting are $\mathrm{CB}$, papaverine, nitrates and phenoxybenzamine, without clear evidence of superiority of one of them ${ }^{33}$. To date, no significant advantages related to skeletonizaton of the conduit, endoscopic harvesting, or utilization of the harmonic scalpel during surgical harvesting have been reported ${ }^{33}$; yet it seem advisable during graft preparation, to avoid hyperinflation and distension of the conduit since would result in damage of the endothelium and the elastic laminae.

\section{Conclusions}

Recent studies have demonstrated superior performance of RA as second conduit for CABG ${ }^{34}$. Nevertheless, it remains unclear whether its patency rate is related to correct indications (e.g. critical coronary artery stenosis), less invasive and/or no-touch harvesting techniques or to the use of antispasmodic drugs.

There are some evidences that support the use CB to ameliorate RA patency ${ }^{24}$, however given the lack of large randomized trials on the specific topic ( $\mathrm{CCB}$ versus no-CCB), final conclusions and recommendations cannot be drawn.

Importantly, the side effects of CB grafting are not negligible and should be taken into account in clinical decision-making.

Finally, understanding the triggers and mechanisms that regulate RA vessel tone and its response to endogenous and exogenous stimulation is pivotal in optimizing RA use as bypass conduit. 


\author{
Abbreviations \\ $\mathrm{CABG}=$ Coronary artery bypass grafting \\ $\mathrm{CB}=$ Calcium-channel blocker \\ $\mathrm{CCB}=$ Chronic calcium-channel blocker \\ LIMA $=$ Left internal mammary artery \\ $\mathrm{RA}=$ Radial artery
}

\title{
References
}

1. Carpentier A, Guermonprez JL, Deloche A, Frechette C and DuBost C. The aorta-to-coronary radial artery bypass graft. A technique avoiding pathological changes in grafts. Ann Thorac Surg . 1973;16:111-21.

2. Kappetein AP and Head SJ. 50th Anniversary Landmark Commentary on Carpentier A, Guermonprez JL, Deloche A, Frechette C, DuBost C. The aorta-to-coronary radial artery bypass graft. Ann Thorac Surg 1973;16:111-21. Ann Thorac Surg . 2015;99:1500.

3. Acar C, Ramsheyi A, Pagny JY, Jebara V, Barrier P, Fabiani JN, Deloche A, Guermonprez JL and Carpentier A. The radial artery for coronary artery bypass grafting: clinical and angiographic results at five years. J Thorac Cardiovasc Surg . 1998;116:981-9.

4. Acar C, Jebara VA, Portoghese M, Beyssen B, Pagny JY, Grare P, Chachques JC, Fabiani JN, Deloche A and Guermonprez JL. Revival of the radial artery for coronary artery bypass grafting. Ann Thorac Surg . 1992;54:652-9; discussion 659-60.

5. Attaran S, John L and El-Gamel A. Clinical and potential use of pharmacological agents to reduce radial artery spasm in coronary artery surgery. Ann Thorac Surg . 2008;85:1483-9.

6. He GW and Yang CQ. Comparison among arterial grafts and coronary artery. An attempt at functional classification. J Thorac Cardiovasc Surg . 1995;109:707-15.

7. van Son JA, Smedts F, Vincent JG, van Lier HJ and Kubat K. Comparative anatomic studies of various arterial conduits for myocardial revascularization. J Thorac Cardiovasc Surg . 1990;99:703-7.

8. Taggart DP. The radial artery as a conduit for coronary artery bypass grafting. Heart . 1999;82:409-10.

9. Chester AH, Marchbank AJ, Borland JA, Yacoub MH and Taggart DP. Comparison of the morphologic and vascular reactivity of the proximal and distal radial artery. Ann Thorac Surg . 1998;66:1972-6; discussion 1976-7.

10. van Son JA and Smedts F. Revival of the radial artery for coronary artery bypass grafting: l'histoire se repete. Ann Thorac Surg. 1993;55:1596-8.

11. Jin N, Siddiqui RA, English D and Rhoades RA. Communication between tyrosine kinase pathway and myosin light chain kinase pathway in smooth muscle. Am J Physiol . 1996;271:H1348-55.

12. Kane-ToddHall SM, Taggart SP, Clements-Jewery H and Roskell DE. Pre-existing vascular disease in the radial artery and other coronary artery bypass conduits. Eur J Med Res . 1999;4:11-4.

13. Brodman RF, Frame R, Camacho M, Hu E, Chen A and Hollinger I. Routine use of unilateral and bilateral radial arteries for coronary artery bypass graft surgery. J Am Coll Cardiol . 1996;28:959-63.

14. Possati G, Gaudino M, Alessandrini F, Luciani N, Glieca F, Trani C, Cellini C, Canosa C and Di Sciascio G. Midterm clinical and angiographic results of radial artery grafts used for myocardial revascularization. $J$ Thorac Cardiovasc Surg . 1998;116:1015-21. 
15. Possati G, Gaudino M, Prati F, Alessandrini F, Trani C, Glieca F, Mazzari MA, Luciani N and Schiavoni G. Long-term results of the radial artery used for myocardial revascularization. Circulation . 2003;108:13504 .

16. Arena $\mathrm{G}$ and Abbate M. [Is calcium antagonist administration necessary after aortocoronary bypass with the radial artery?].Ital Heart J Suppl . 2000;1:256-8.

17. Shapira OM, Alkon JD, Macron DS, Keaney JF, Jr., Vita JA, Aldea GS and Shemin RJ. Nitroglycerin is preferable to diltiazem for prevention of coronary bypass conduit spasm. Ann Thorac Surg . 2000;70:883-8; discussion 888-9.

18. Gaudino M, Glieca F, Luciani N, Alessandrini F and Possati G. Clinical and angiographic effects of chronic calcium channel blocker therapy continued beyond first postoperative year in patients with radial artery grafts: results of a prospective randomized investigation. Circulation . 2001;104:I64-7.

19. Gaudino M, Luciani N, Nasso G, Salica A, Canosa C and Possati G. Is postoperative calcium channel blocker therapy needed in patients with radial artery grafts? J Thorac Cardiovasc Surg . 2005;129:532-5.

20. Gaudino M, Prati F, Caradonna E, Trani C, Burzotta F, Schiavoni G, Glieca F and Possati G. Implantation in coronary circulation induces morphofunctional transformation of radial grafts from muscular to elastomuscular. Circulation . 2005;112:I208-11.

21. Moran SV, Baeza R, Guarda E, Zalaquett R, Irarrazaval MJ, Marchant E and Deck C. Predictors of radial artery patency for coronary bypass operations. Ann Thorac Surg . 2001;72:1552-6.

22. Cameron J, Trivedi S, Stafford G and Bett JH. Five-year angiographic patency of radial artery bypass grafts. Circulation . 2004;110:II23-6.

23. Miwa S, Desai N, Koyama T, Chan E, Cohen EA, Fremes SE and Radial Artery Patency Study I. Radial artery angiographic string sign: clinical consequences and the role of pharmacologic therapy. Ann Thorac Surg . 2006;81:112-8; discussion 119.

24. Gaudino M, Benedetto U, Fremes SE, Hare DL, Hayward P, Moat N, Moscarelli M, Di Franco A, Nasso G, Peric M, Petrovic I, Puskas JD, Speziale G, Yoo KJ, Girardi LN, Taggart DP and Investigators R. Effect of Calcium-Channel Blocker Therapy on Radial Artery Grafts After Coronary Bypass Surgery. J Am Coll Cardiol . 2019;73:2299-2306.

25. Myers MG and Fremes SE. Prevention of radial artery graft spasm: a survey of Canadian surgical centres. Can J Cardiol . 2003;19:677-81.

26. He GW and Yang CQ. Comparative study on calcium channel antagonists in the human radial artery: clinical implications. J Thorac Cardiovasc Surg . 2000;119:94-100.

27. Bleiziffer S, Hettich I, Eisenhauer B, Ruzicka D, Wottke M, Hausleiter J, Martinoff S, Morgenstern M and Lange R. Patency rates of endoscopically harvested radial arteries one year after coronary artery bypass grafting. J Thorac Cardiovasc Surg . 2007;134:649-56.

28. Kloner RA, Sowers JR, DiBona GF, Gaffney M and Wein M. Sex- and age-related antihypertensive effects of amlodipine. The Amlodipine Cardiovascular Community Trial Study Group. Am J Cardiol . 1996;77:713-22.

29. Kolandaivelu K, Leiden BB, O'Gara PT and Bhatt DL. Non-adherence to cardiovascular medications. Eur Heart $J$. 2014;35:3267-76.

30. Blitz A, Osterday RM and Brodman RF. Harvesting the radial artery.Ann Cardiothorac Surg . $2013 ; 2: 533-42$.

31. Royse AG, Royse CF, Tatoulis J, Grigg LE, Shah P, Hunt D, Better N and Marasco SF. Postoperative radial artery angiography for coronary artery bypass surgery. Eur J Cardiothorac Surg . 2000;17:294-304. 
32. Desai ND, Naylor CD, Kiss A, Cohen EA, Feder-Elituv R, Miwa S, Radhakrishnan S, Dubbin J, Schwartz L, Fremes SE and Radial Artery Patency Study I. Impact of patient and target-vessel characteristics on arterial and venous bypass graft patency: insight from a randomized trial. Circulation . 2007;115:684-91.

33. Gaudino M, Crea F, Cammertoni F, Mazza A, Toesca A and Massetti M. Technical issues in the use of the radial artery as a coronary artery bypass conduit. Ann Thorac Surg . 2014;98:2247-54.

34. Gaudino M, Benedetto U, Fremes S, Biondi-Zoccai G, Sedrakyan A, Puskas JD, Angelini GD, Buxton B, Frati G, Hare DL, Hayward P, Nasso G, Moat N, Peric M, Yoo KJ, Speziale G, Girardi LN, Taggart DP and Investigators R. Radial-Artery or Saphenous-Vein Grafts in Coronary-Artery Bypass Surgery. N Engl $J$ Med . 2018;378:2069-2077. 